\title{
THE TRADING AND INDUSTRIAL GILDS
}

T NTIL the recent publication of Mr. Westlake's interesting volume upon The Parish Gilds of Medieval England, * students were apt to devote far too exclusive attention to Gilds of the kind I propose to deal with in this article. There were two main reasons for this preference : firstly, there was much more copious material available concerning the Trade and Craft Gilds; secondly, they were of a nature that appeals more readily to modern " practical " Englishmen. Yet it must not be forgotten that the early and normal Gilds in England were Religious Gilds, Confraternities having primarily a religious purpose, and only as a by-product any sort of social or industrial services.t The Trading and Industrial Gilds were later developments, existing side by side with, and in imitation of, the Religious Gilds. They fall into two clearly marked classes - the Gilds-merchant and the Craft Gilds.

A.-The Gilds-merchant. The Gilda Mercatoria, or Merchant-Gild, which is the earlier kind, seems in its origin to have been composed, not only of those who carried on trade from town to town and in foreign countries, but also of all the craftsmen of any sort in each town. We hear of it by name first in the end of the eleventh century. But it is very probable that some at least of the Cnighten-Gilds, of which we hear in Saxon times, were, or developed into, Merchant-Gilds. Certainly that at Canterbury was described indifferently as the Gild of Cnights at Canterbury or the Ceapmann-Gild, and Dr. Gross has shown that the

- S.P.C.K., London, I9I9.

$\dagger$ An analogy may be found in the Religious Orders, which were primarily organizations for the sanctification of the individual and the defence of the Church, but which became, incidentally as it were, such potent instruments for the civilization of Europe. 


\section{The Trading and Industrial Gilds}

word "cnight" was often used in charters as a synonym of "townsman." However that may be, we find a Gild-merchant mentioned in a Burford charter of 1087, while, as time goes on, these bodies appear established in about one hundred English towns. Curiously enough there never seems to have been a Gild-merchant in such important towns as London, Norwich and the Cinque Ports. It is true one thirteenth century document mentions a Gild-merchant in London, but this seems to be a mere clerk's error. As to the Cinque Ports, they had such privileges of all sorts that a Gild-merchant would have been unnecessary, while at Norwich and some other towns the Religious Gilds seem to have taken its place. The direct object of a Gild-merchant appears to have been to control the conditions of trading in the town where it was established. Its main feature, as Lipson puts it, " consisted in the exclusive right of its members to buy and sell within the borough, retail and wholesale, on market days and all other times without payment of toll or custom." Sometimes this privilege was extended to all burgesses, but usually it was confined to the members of the Gild-merchant. Others might take a limited part in the wholesale trade of the town, provided they paid toll, but only the gildsmen were allowed to undertake retail trade. Thus the Gild authorities were able to control both the quality of the goods sold and the conditions of their production, while at the same time "cutting" competition from outside was impossible.

Another important privilege that obtained in the Gild-merchant was that all members of the Gild had the right to share in any transaction by a fellow gildsman. Thus if one gildsman bought a large supply of cloth from a foreign merchant, every other gildsman in the town who was present when the bargain was made, had a right to share in the purchase at the original 


\section{Blackfriars}

price paid. This privilege, which seems to us hard on the original purchaser, was deliberately made to prevent the richer members of the community from buying up all available goods to the detriment of the poorer gildsmen. Later this privilege gave rise to co-operative purchasing by the Gild authorities for the equal benefit of the Gild members, who had the first claim upon all such bargains. Nor does this by any means exhaust the list of benefits arising from membership of a Gild-merchant. If a gildsman fell sick, he was visited and supplied with remedies and dainties; if he became poor, he was helped from the Gild funds; if he found himself in prison, as was not infrequent in those days of rough and ready justice, the officers of his Gild took steps to procure his release. Further, the mere fact that he was a member of a powerful and recognized organization greatly strengthened his commercial position. If he went out to trade with another town, his Gild officers would provide him with a letter of recommendation, or " test," to those into whose district he was going. If he got into trouble there or elsewhere, his Gild at home would take up his cause and often procure him a fair hearing. The Gild of one town would not infrequently make an agreement with the Gild of another, whereby their members should share privileges in their respective areas. In some instances a Royal charter would grant to the gildsmen of a favoured town freedom from toll throughout the Realm. Last, and by no means least, a Gild usually made itself responsible for the debts of its members, this greatly enhancing their credit in other towns. And the right of "withernam," that is, of distraining on the goods of any fellow-townsman of a defaulting debtor who happened to be within reach, which was in time conferred by charter upon many towns, made it in every way expedient that Gild authorities should see to it that their members paid their debts. 


\section{The Trading and Industrial Gilds}

Of course, the privileges of a Gild-merchant were, like all human institutions, liable to be abused. But, in this country at any rate, the abuse seems to have been much less than is sometimes assumed. In England but little record has come down to us of that oppression of the poorer craftsmen by wealthy Gild members that caused such disturbances in the Scottish and Continental towns. It is true that in London and elsewhere we hear complaints in the twelfth century of the weavers being excluded from Gild privileges and burgess-ship ; but this seems to be not unconnected with the undoubted fact that most of the weavers in that early period were, or had been, foreign immigrants, whom native traders and craftsmen looked on askance. Butchers and tanners, too, for some reason, were apt to be excluded from the Gilds-merchant so long as they exercised their trades, but this may have been due to the unpleasant nature of their trades. A yet more important reason was the attempt of the weavers and others, by purchasing charters from the King, to stand out of the common burdens of civic life, a procedure which the municipalities naturally resented. Certainly all sorts of craftsmen - carpenters, cooks, fishermen, inn-keepers, builders and othersare found on the lists of Gild members, and there is no evidence that they were oppressed by the merchants.

Then again, undoubtedly, as a Gild became more powerful, its members tended to have more influence in local municipal affairs. In some cases the Gild officers were at the same time the municipal officers. But in England, with its strong central government that fostered municipal growth, the Gild-merchant never took the place of, or attained to complete control over, the municipality. To quote Lipson, "It was an important element in the civic constitution, but it was subordinate to and not identical with the municipal government!" 


\section{Blackfriars}

A gildsman generally was also a burgess, but there were many burgesses who were not gildsmen and some gildsmen who were not burgesses. Even in the greatest days of the Gild-merchant it was subject to the ultimate control of the town authorities, though these very authorities might be its own members.

As time went on, however, and town life became more complex and industrial processes became more specialized, it ceased to be possible for the Gild-merchant to include and control all the various crafts. While the merchants and general traders tended to form trading companies, the various crafts tended to split off into independent craft organizations. For some time the Gild-merchant resisted this tendency, but social development was not to be prevented, and the Craft Gilds were successful in establishing their right to independent existence. By the fourteenth century the Gild-merchant had become an obsolete institution, and we hear but little of it in later years.

B.-The Craft Gilds. Though the great period of the Craft Gilds does not come till the end of the thirteenth century, we hear of them at least two hundred years earlier. As far back as the reign of Henry I we find the weavers already organized on craft lines in London, Winchester, and Oxford, while the Bakers' Gild appears in London in the reign of his son. But these seem to have been exceptions. The textile trades, indeed, for some reason appear throughout English history to be among the earliest to adopt new forms of industrial life, while the organization and control by public authority of anything affecting the food of the people is a characteristic of medieval life.

But it is not till the fourteenth century in this country that the wider and looser organization of the Gild-merchant definitely gives place to more specialized bodies like the Craft Gilds. The fourteenth and fifteenth century, indeed, while certainly showing a 


\section{The Trading and Industrial Gilds}

grievous and increasing weakening of the Christian spirit that had slowly rebuilt European civilization, are yet remarkable as displaying the power of Christian tradition to give birth to wholesome social organizations. Every town was a centre of vivid, energetic life, municipal government developed and consolidated rapidly, while industrial life produced innumerable Gilds, regulating and protecting every kind of industry. The Craft Gilds took over and developed the industrial work of the Gilds-merchant. Every detail of industrial life was subject to their control. They regulated the buying of the materials, the conditions of life for the workers, the quality of the goods produced, and the price at which they were to be laid before the public. Their officers examined the quality of the raw. materials, and destroyed or forbade the sale of unsound items. They condemned unsound work, haled recalcitrant tradesmen before the magistrates, chastised unruly apprentices, and dealt severely with tyrannical masters. The court of each Gild settled the number of journeymen and apprentices that each master might employ and the terms of their employment, heard appeals of aggrieved members against the action of the Gild wardens or some Gild brother, laid down the proportion of the Gild funds that were to be expended on religious services or pageants, settled the details of the annual dinners and Gild meetings, arranged for the care and helping of sick or indigent brothers and their families, collected and paid to the King or the municipality the due taxes, sometimes consulted how the Gild might evade new burdens laid upon it by the Powers in being. In all their recorded actions we find that same mixture of business ability, blunt common sense and sturdy faith that is characteristic of the English in the Middle Ages.

All the Craft Gilds consisted of the threefold system of apprentices, journeymen and masters and, in the 


\section{Blackfriars}

earlier days at any rate, the same persons were in succession all three. Apprenticeship was the basis of the whole organization: the idea that each lad should learn his trade thoroughly by long service in the house and under the tuition of a master skilled in the craft. The time assigned to apprenticeship varied; mostly it was for seven years, but not infrequently it was for shorter or longer terms. Thus the Fullers of Northampton only required four years training, while the Lorimers (harness makers) of London insisted upon ten years. Sometimes, as among the Girdlers at York, it was found necessary to extend the term previously thought sufficient. The age at which apprentices were taken varied from fourteen for the Norwich weavers to eighteen for the London carpenters, though cases are known in which children of eleven were apprenticed. The apprentice, by the terms of his indentures, usually received board and lodging, clothes, instruction, and some small amount of pocketmoney from his master. In return he was bound to be diligent, obedient, careful and regular, and was subject to reasonable chastisement if he failed in any of these particulars. But the chastisement had to be reasonable, or the master was liable to punishment by his Gild. When the end of his apprenticeship arrived, the apprentice became a journeyman, that is, a workman paid wages by a master, who was not always the master who had trained him. After an interval of about three years, the journeyman, if he could show his capacity to do so, technically and financially, was allowed to take apprentices of his own and so become a master. Thus, from the time when he first began to learn his craft to the end of his life as a master and perhaps a prosperous burgess, the craftsman's life was controlled and protected by his Gild.

As time went on the Craft Gilds took more and more part in the civic and religious life of the towns. Their 


\section{The Trading and Industrial Gilds}

members became Mayors and leading members of the Town Councils ; their Gild funds were lavishly expended to maintain the Gild Chapel and masspriest in their Parish Church, their pageant became a regular and expected part of the Corpus Christi procession, their annual Feast Day was a notable occasion for junketings and for the distribution of alms to the poor. The Craft Gilds became at once religious confraternities, friendly societies, arbitration courts, regulators of prices and of the conditions of work, schools of drama and ceremonial, providers of charitable relief and of education, training schools of civic administration. On the whole, though of course with many lapses, they were the finest example of Christian Democracy that has yet been vouchsafed to this world of fallible human beings. Had they not been destroyed, there is good reason to believe that we should never have been cursed with the heathen capitalism that now dominates and vitiates modern society. But, from the middle of the sixteenth century, their decline was rapid and tragic and, though it does not come within the medieval period, it is perhaps worth while to spend a little time in examining the causes of their fall.

First of all, we must guard ourselves against the prevalent misconception that the Craft Gilds were deliberately destroyed by the Governments of Henry VIII, Edward VI, and Elizabeth. It would be nearer the truth to say that they used every means they could think of to preserve them. Henry VIII followed his father's policy of regulating and controlling the Gilds by legislation, and his Acts of I53I and I537 are genuine attempts to make the Gilds more efficient and less exclusive. The Government of Edward VI certainly did not intend to destroy the Craft Gilds ; indeed, they are expressly exempted from the operation of the Act of 1547 , which destroyed the 


\section{Blackfriars}

Religious Gilds. Elizabeth, whom Professor Ashley considers to have seriously affected their status by the Statute of Apprentices of 1563 , did no more by that Act than to consolidate the legislation as to wages and apprenticeship that had been in operation for two hundred years. That she was not opposed to the Craft Gilds is shown by the numerous charters granted to new Gilds and re-approvals of the regulations of old Gilds that date from her reign. Indeed, we find new charters granted to Gilds as late as the latter half of the seventeenth century. The Gilds died, in spite of strenuous attempts by successive Governments to keep them alive.

Must we, then, agree with the other school, which holds that the Gilds decayed because they were reactionary and mischievous bodies, which had outlived any usefulness that they may have had in a less enlightened society? Not by any means. It is true that, by the middle of the sixteenth century, the Craft Gilds had lost not a little of the spirit that pervaded them in earlier times and were in danger of transformation from democratic industrial organizations to close corporations of the wealthier burgesses. Not only had some of the greater Gilds in London, like the Mercers, the Goldsmiths, the Grocers and others, become chartered companies more intent upon the enrichment of their members than upon the promotion of their craft, but all over England the Gilds were tending to exclude the poorer craftsmen from membership, by excessive fees, by insistence on the wearing of expensive liveries, by undue limitation of apprenticeship, and generally by all the means whereby the wealthy are wont to separate themselves from their poorer brethren. The exclusiveness of the Gilds, coupled with their determination to control industry and to subjugate those whom they continued to debar from their privileges, constituted a grave evil 


\section{The Trading and Industrial Gilds}

that called for Governmental interference. The ever growing number of journeymen who could never hope to become masters, had a real grievance against the Gilds who made mastership so difficult. And this exclusiveness brought with it the usual penalty of imperviousness to what was sound in the newer economic ideas of the period.

But, though this was a serious degeneration from earlier ideas, it implied no decay beyond hope of recovery. What really made rapid decline inevitable was the growth of an alien force outside them, coupled with the destruction of the Faith upon which they were founded and out of which they had grown.

One of the most notable results of the decline of the medieval spirit is the prompt reappearance of something that had not been seen since the fall of pagan Rome-Capitalism-the tendency to concentrate the control of wealth and industry into a few hands. Already it had its beginnings in the rise of the woollen industry in the fourteenth and fifteenth centuries, with the disastrous results to the rural poor so graphically described by Sir Thomas More and others. But the moral instinct of the time was against it and the power of the state still restrained it, while, as Lipson writes, "the Craft Gilds did all in their power to prevent the growth of industrial capitalism among their own members." There is little doubt that the evil might have been checked and the newer industrial methods diverted into co-operative channels but for the enormous economic revolution resulting from Henry VIII's ecclesiastical spoliation. By the confiscation of Church property and its rapid transference to the hands of a crowd of greedy adventurers, a new capitalist class was created, enormously more powerful than any that had yet been known in England, interested in combining to prevent any return to earlier conditions and unrestrained by the moral and religious beliefs 


\section{Blackfriars}

that had had some considerable influence over earlier capitalists.

To this horde of "New Men," the bias of the Gild system towards " order rather than progress, stability rather than expansion," its hatred of capitalism and preference for co-operative democracy, its suspicion of new methods that might react unfairly on its weaker members; all these things were an offence, and deliberately they set themselves to ignore its spirit, to evade its regulations, and to render it obsolete. Uncontrolled capitalism and the Gild system were incompatible.

At the very moment when the Gilds were confronted by this alien force, their funds were curtailed, their prestige was shattered, and the spirit that informed them was destroyed by the Government's ecclesiastical policy. For, though the Craft Gilds were expressly exempted from the destruction that fell upon the Religious Gilds, yet any funds that they were wont to expend for Religious purposes were confiscated and the record of their efforts to evade this show how serious a blow this was to their resources. At the same time, the ruthless destruction of thousands of Religious and Social Gilds in almost every parish throughout England must have been a terrible blow to the prestige of the remaining Craft Gilds, which were often not easily distinguishable from them.

Finally, the Gilds were the product of Catholicism ; it was Catholic doctrine that lay at the root of their ordinances and practice, it was to Catholic morals alone that constant appeal could be made to check the human frailties of their members. When Catholicism was banished from England and the whole power of Church and State was employed to inculcate an alien doctrine and an alien view of personal and social obligation, the virtue was gone out of the Gilds; there was no spirit left in them that was capable of resistance to the newer economics. So their decline 


\section{The Trading and Industrial Gilds}

was rapid and hopeless. They lingered on as ghosts of their former selves till the end of the eighteenth century ; indeed, the great Liveried-Companies remain as interesting survivals to this day. But for all practical purposes they had ceased to count industrially by the middle of the seventeenth century ; capitalist individualism had triumphantly swept them aside and has dominated England ever since.

\section{SHORT BIBLIOGRAPHY}

Armitage, F. The Old Guilds of England. I9I8.

AsHLEY, W. J. An Introduction to English Economic History and Theory. 2 vols. I9I2-I3.

Ashley, W. J. Surveys, Historic and Economic. Ig00.

BATESON, M. Records of the Borough of Leicester. 2 vols. I899-I900.

Bateson, M. Cambridge Gild Records. Ig03.

CunninghaM, W. Growth of English Industry and Commerce. Vol. I. IgI5.

Gasguet, Cardinal F. A. The Eve of the Reformation. 1900 .

Green, Alice. Town Life in the Fifteenth Century. 2 vols. I894.

Gross, C. The Gild Merchant. 2 vols. I89o.

HIBBERT, F. A. The Influence and Development of English Gilds. I89r.

Husslein, J., Democratic Industry. I9I9.

KRAMER, S. The English Craft Gilds and the Government. I905.

LAMcBers, J. M. Two Thousand Years of Gild Life. I89r. LeACH, A. F. Beverley Town Documents. 1900.

LIPSON, E. The Economic History of England. Vol. I. IgI5. Seligman, E. R. A. Two Chapters on the Medieval Gilds of England. I887.

Smrth; J. Toulmin. English Gilds. 1870.

TraILL, H. D., ed. Social England. Vols. I, II, III. I895.

UNWIN, G. The Guilds and Companies of London. I908.

WEstlake, H. F. The Parish Gilds of Medieval England. IgIg.

LESLIE A. TOKE. 